\title{
PENGARUH SUBSTITUSI TEPUNG TERIGU DENGAN TEPUNG SAGU TERHADAP TINGKAT KESUKAAN BOLU KEMOJO
}

\author{
Dian Agusti Ramadhani, Sri Mulyani \\ * Jurusan Gizi Politeknik Kesehatan Kemenkes Riau
}

\begin{abstract}
ABSTRAK
Tepung terigu menjadi produk pertanian yang penting bagi masyarakat Indonesia karena tepung terigu telah menjadi bahan baku banyak olahan makanan. Tingkat produksi dan permintaan yang tinggi menyebabkan tingginya harga tepung. Keadaan ini memacu pengembangan upaya produk alternatif pengganti. Sagu merupakan salah satu komoditas yang dapat dijadikan sebagai alternatif pengganti terigu dan merupakan bahan baku pangan lokalPropinsi Riau.Bolu kembojo merupakan salah satu jenis pangan tradisional Riau yang dipopulerkan pada tahun 1997.

Tujuan penelitian ini adalah untuk mengetahui pengaruh substitusi tepung terigu dengan tepung sagu terhadap tingkat kesukaan bolu kemojo.Penelitian ini merupakan penelitian eksperimen menggunakan Rancangan Acak Lengkap (RAL) dengan 5 perlakuan substitusi tepung terigu dengan tepung sagu yaitu $0 \%, 25 \%$, $50 \%, 75 \%$ dan $100 \%$ dan kontrol tanpa menggunakan tepung sagu, dilakukan uji tingkat kesukaan terhadap produk, kemudian data dianalisa menggunakan analisa sidik ragam satu arah yang dilanjutkan dengan uji Duncan's.

Hasil penelitian ini adalah produk bolu krmojo dengan 5 formula yang menyatakan bahwa adanya pengaruh subtitusi tepung terigu dengan tepung sagu terhadap tingkat kesukaan rasa, aroma, warna dan tekstur.
\end{abstract}

\section{Kata Kunci : Bolu kemojo, Sagu, Uji Organolepti}

\section{PENDAHULUAN}

Salah satu produk pertanian yang menjadi kebutuhan pokok masyarakat Indonesia adalah tepung terigu. Tepung terigu menjadi produk yang penting bagi masyarakat Indonesia karena tepung terigu telah menjadi bahan baku yang telah banyak digunakan untuk menghasilkan berbagai macam produk makanan. Tingkat produksi tepung terigu nasional yang masih rendah dan tingginya permintaan produk tepung terigu menyebabkan harga tepung terigu dirasakan konsumen masihtinggi. Keadaan ini memacu pengembangan berbagai upaya untuk menciptakan produk alternatif yang mampu menyubstitusi tepung terigu. (Salim, 2011)

Sagu (Metroxylon merupakan tanaman palma penghasil pati (sumber karbohidrat) dan menempati posisi keempat setelah ubi kayu, jagung dan ubi jalar. Tanaman sagu terbesar di Kawasan Timur Indonesia terutama Maluku, Papua, Sulawesi dan sebagian wilayah Barat Indonesia terutama Riau. Produksi Sagu pada tahun 2014 adalah 310.656 ton, 423.946 ton pada tahun 2015 dan 440.516 pada tahun 
2016 (Kementerian pertanian, 2016). Sagu dapat dimanfaatkan sebagai bahan baku industri pangan yang antara lain dapat diolah menjadi bahan makanan seperti bagea, mutiara sagu, kue kering, mie, biskuit, kerupuk dan laksa(Haliza dan Iriani, 2006). Sagu merupakan salah satu komoditas yang dapat dijadikan sebagai alternatif pengganti terigu dan merupakan bahan baku pangan tradisonal di Propinsi Riau.

Pangan tradisional adalah makanan yang dikonsumsi masyarakat golongan etnik dan wilayah spesifik, diolah dari resep yang dikenal masyarakat, bahanbahannya diperoleh dari sumber lokal dan memiliki rasa yang relatif sesuai dengan selera masyarakat setempat. Pangan tradisional Indonesia terbuat dari beragam bahan mentah seperti beras, jagung, umbi-umbian, tepungtepungan, sayur-sayuran, buahbuahan, kelapa, ikan, unggas, daging, susu, serta rempah-rempah, dengan aneka ragam resep dan proses pengolahan. Pangan tradisional tersebut dikonsumsi sebagai makanan lengkap, hidangan camilan/ kue, dan sebagai minuman. Pangan tradisonal mempunyai potensi yang besar untuk dikembangkan karena dapat meningkatkan perekonomian masyarakat dan pendapatan asli daerah, peningkatan status gizi dan kesehatan masyarakat, dan untuk wisata boga.

Bolu kembojo merupakan salah satu jenis pangan tradisional Riau yang dahulunya kurang dikenal karena pada zaman dahulu bolu kembojo atau yang lebih sering disebut bolu kemojo ini hanya dapat dinikmati pada acara-acara tertentu seperti upacara adat atau pernikahan. Tahun 1997, Ibu Dinawati mulai memperkenalkan dan mempopulerkan bolu kemojo inisehingga sekarang tidak sulit lagi untuk menemukan makanan ini bila berkunjung ke daerah Riau. (Rusydianti, 2012).

Pada umumnya kue bolu kemojo dibuat dari tepung terigu sebagai bahan utama, dicampur dengan telur, santan, gula serta daun pandan. Melihat penggunaan terigu yang semakin meningkat dan potensi ketersediaan pangan lokal yang juga melimpah maka penulis tertarik untuk menggantikan penggunaan tepung terigu dengan tepung sagu dalam pembuatan bolu kemojo.

\section{METODE PENELITIAN}

\section{Bahan}

Sampel dalam penelitian ini adalah bolu kemojo yang disubtitusikan dengan tepung sagu menggunakan 5 formula.

\section{Tahapan Penelitian}

Penelitian ini terdiri atas tahap persiapan bahan penelitian, pembuatan produk, persiapan contoh uji organoleptik, uji organoleptik serta analisa data. Alir penelitian dapat dilihat pada Gambar 3.1. 


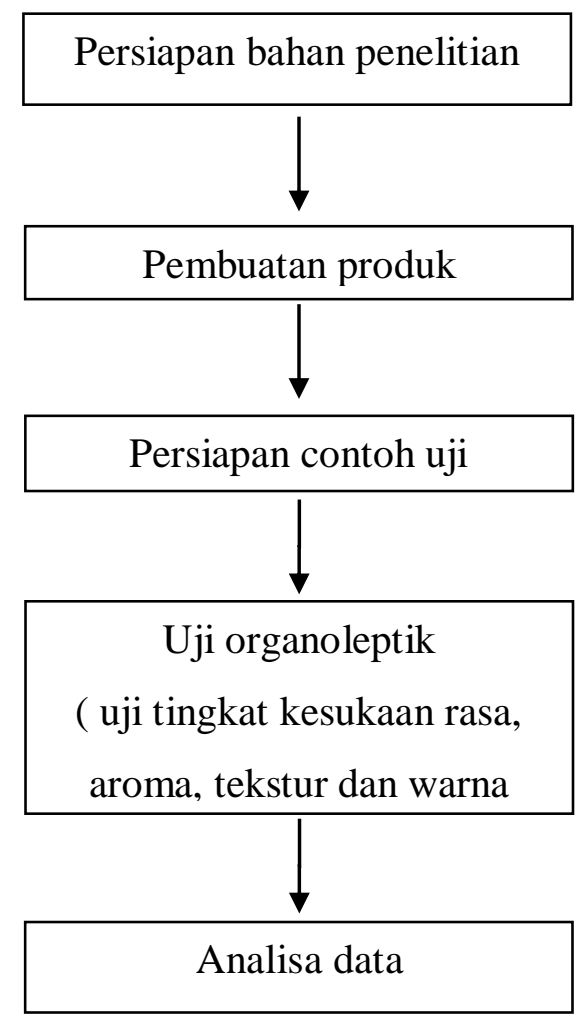

\subsection{Kerangka Konsep Penelitian}

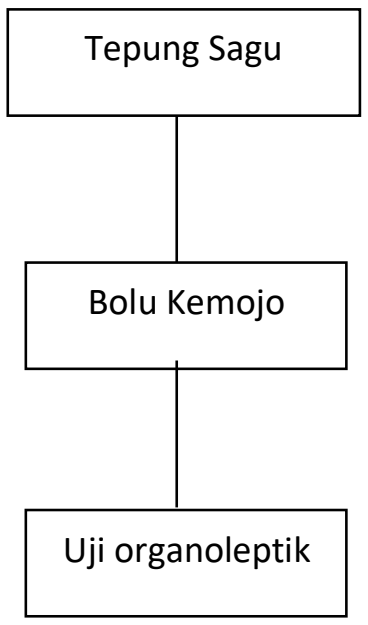

Gambar 3.2. Kerangka Konsep Penelitian

\subsection{Desain Penelitian}

Penelitian ini merupakan penelitian eksperimen menggunakan Rancangan Acak Lengkap (RAL) dengan 5 perlakuan.

\subsection{Analisa Data}

Penelitian ini bersifat eksperimental dengan desain penelitian rancangan acak lengkap. Data yang diperoleh dari hasil pengujian disajikan dalam bentuk rata-rata dan standar deviasi, kemudian dilakukan analisa sidik ragam (Anova) satu arah dan dilanjutakan dengan uji Duncan.

\section{HASIL DAN PEMBAHASAN Deskripsi Produk}

Produk bolu kemojo dari tepung sagu adalah suatu produk baru yang dibuat dari percampuran tepung sagu dengan tepung sagu serta bahan penunjang lainnya seperti gula pasir, margarin, telur ayam, santan, vanili, garam dan daun pandan. Rasa dari bolu kemojo adalah manis, warna yang di hasilkan yaitu warna hijau dan agak kecoklatan, tekstur yang dihasilkan adalah kenyal, semakin banyak tepung sagu yang di tambahkan maka semakin padat dan semakin kenyal tekstur yang di hasilkan, dan aroma yang dihasilkan dari bolu kemojo tidak berbeda jauh dengan aroma asli bolu kemojo.

Bolu kemojo akan di lakukan penilaian uji organoleptik atau tingkat kesukaan panelis yang meliputi warna, aroma, rasa dan tekstur. Adapun perbandingan tepung yang digunakan adalah $0 \%: 100 \%$, $25 \%: 75 \%, 50 \%: 50 \%, 75 \%: 25 \%$, 100\%:0\%.

\section{Uji Organoleptik ( Uji Hedonik)}

Uji organolepti adalah penilaian dengan menggunakan alat indera, yaitu indera penglihatan, penciuman, pengecap dan pendengaran untuk mengukur daya terima suatu produk. Pengujian 
organoleptik memiliki peranan mutu produk

Tabel.1 Uji Duncan Tingkat Warna Bolu Kemojo

\begin{tabular}{|c|c|c|c|c|}
\hline \multicolumn{2}{|c|}{$\begin{array}{c}\text { Kode } \\
\text { Sampel }\end{array}$} & $\begin{array}{c}\text { Selisih } \\
\text { Rata2 }\end{array}$ & $\begin{array}{c}\text { nilai } \\
\text { pembanding }\end{array}$ & Kesimpulan \\
\hline \hline 403 & 378 & 0,1 & 0,28 & Sama \\
\hline & 485 & 0,35 & 0,296 & Beda \\
\hline & 396 & 0,425 & 0,302 & Beda \\
\hline & 368 & 0,45 & 0,315 & Beda \\
\hline 378 & 485 & 0,25 & 0,28 & Sama \\
\hline & 396 & 0,325 & 0,296 & Beda \\
\hline & 368 & 0,35 & 0,302 & Beda \\
\hline 485 & 396 & 0,075 & 0,28 & Sama \\
\hline & 368 & 0,1 & 0,296 & Sama \\
\hline 396 & 368 & 0,025 & 0,28 & Sama \\
\hline & & \multicolumn{3}{c}{} \\
\hline
\end{tabular}

Berdasarkan uji duncan, diketahui tidak terdapat perbedaan nyata antara sampel 403 dengan sampel 378, sementara dengan sampel lainnya terdapat perbedaan nyata. Sementara warna yang paling disukai adalah pada sampel 403 dibandingkan sampel lainnya. Hal ini karena perlakuan 403 tidak dilakukan penambahan tepung sagu sehingga warna yang dihasilkan bewarna lebih hijau, sampel 403 menggunakan bahan $100 \%$ tepung terigu dengan penambahan bahan lainnya sama dengan formula lainnya, sementara pada sampel 485, 378, 368, 396 yang ditambahkan tepung sagu dihasilkan warna hijau yang lebih pucat. Pada formula 396 warna yang dihasilkan agak berbeda dengan formula lainnya karena penggunaan $100 \%$ tepung sagu, pada bagian pinggir bolu kemojo cenderung lebih cepat matang sehingga ada perbedaan warna yang cukup signifikan, karena pada bagian tengah bolu masih bewarna hijau khas daun suji sementara bagian pinggir bolu kemojo telah memgalami perubahan warna menjadi coklat.
Tabel 2. Uji Duncan Tingkat Rasa Bolu Kemojo

\begin{tabular}{|c|c|c|c|c|}
\hline \multicolumn{2}{|c|}{$\begin{array}{c}\text { Kode } \\
\text { Sampel }\end{array}$} & $\begin{array}{c}\text { Selisih } \\
\text { Rata2 }\end{array}$ & $\begin{array}{c}\text { nilai } \\
\text { pembanding }\end{array}$ & Kesimpulan \\
\hline \hline 378 & 403 & 0,05 & 0,336 & Sama \\
\hline & 485 & 0,5 & 0,3552 & Beda \\
\hline & 368 & 0,9 & 0,3624 & Beda \\
\hline & 396 & 1,325 & 0,378 & Beda \\
\hline 403 & 485 & 0,45 & 0,336 & Beda \\
\hline & 368 & 0,85 & 0,3552 & Beda \\
\hline & 396 & 1,275 & 0,3624 & Beda \\
\hline 485 & 368 & 0,4 & 0,336 & Beda \\
\hline & 396 & 0,825 & 0,3552 & Beda \\
\hline 368 & 396 & 0,425 & 0,336 & Beda \\
\hline
\end{tabular}

Berdasarkan uji duncan, diketahui tidak terdapat perbedaan nyata antara sampel 403 dengan sampel 378, sementara dengan sampel lainnya terdapat perbedaan nyata. Sementara rasa yang paling disukai adalah pada sampel 378 dibandingkan sampel lainnya. Hal ini disebabkan oleh penambahan tepung sagu $50 \%$ dan 50\% tepung terigu sementara bahan lainnya jumlah yang digunakan sama ke dalam bolu kemojo yang menciptakan rasa yang berbeda.

\section{Tabel 3. Uji Duncan Tingkat} Aroma Bolu Kemojo

\begin{tabular}{|r|r|r|r|l|}
\hline \multicolumn{2}{|r|}{ Kode Sampel } & $\begin{array}{l}\text { Selisih } \\
\text { Rata2 }\end{array}$ & $\begin{array}{l}\text { nilai } \\
\text { pembanding }\end{array}$ & Kesimpulan \\
\hline \hline 378 & 403 & 0,075 & 0,294 & Sama \\
\hline & 485 & 0,3 & 0,3108 & Sama \\
\hline & 368 & 0,425 & 0,3171 & Beda \\
\hline & 396 & 0,825 & 0,3308 & Beda \\
\hline 403 & 485 & 0,225 & 0,294 & Sama \\
\hline & 368 & 0,35 & 0,3108 & Beda \\
\hline & 396 & 0,75 & 0,3171 & Beda \\
\hline 485 & 368 & 0,125 & 0,294 & Sama \\
\hline & 396 & 0,525 & 0,3108 & Beda \\
\hline 368 & 396 & 0,4 & 0,294 & Beda \\
\hline
\end{tabular}


Berdasarkan uji duncan, diketahui tidak terdapat perbedaan nyata antara sampel 403 dengan sampel 378 dan sampel 485, sementara dengan sampel lainnya terdapat perbedaan nyata. Sementara aroma yang paling disukai adalah pada sampel 378 dibandingkan sampel lainnya. Hal ini disebabkan oleh penambahan tepung sagu 50\% dan $50 \%$ tepung terigu ke dalam bolu kemojo yang menciptakan aroma yang berbeda. Sementara pada sampel 368 dan 396 kurang disukai oleh panelis.

Tabel 4. Uji Duncan Terhadap Tekstur Bolu Kemojo

\begin{tabular}{|c|c|c|c|c|}
\hline \multicolumn{2}{|c|}{ Kode Sampel } & $\begin{array}{c}\text { Selisih } \\
\text { Rata2 }\end{array}$ & $\begin{array}{c}\text { Nilai } \\
\text { Pembanding }\end{array}$ & Kesimpulan \\
\hline \hline 403 & 378 & 0,25 & 0,3192 & Sama \\
\hline & 485 & 0,55 & 0,33744 & Beda \\
\hline & 368 & 0,825 & 0,34428 & beda \\
\hline & 396 & 1,25 & 0,3591 & beda \\
\hline 378 & 485 & 0,3 & 0,3192 & sama \\
\hline & 368 & 0,575 & 0,33744 & beda \\
\hline & 396 & 1 & 0,34428 & beda \\
\hline 485 & 368 & 0,275 & 0,3192 & sama \\
\hline & 396 & 0,7 & 0,33744 & beda \\
\hline 368 & 396 & 0,425 & 0,3192 & beda \\
\hline
\end{tabular}

Berdasarkan uji duncan, diketahui tidak terdapat perbedaan nyata antara sampel 403 dengan sampel 378, sementara dengan sampel lainnya terdapat perbedaan nyata. Sementara tekstur yang paling disukai adalah pada sampel 403 dibandingkan sampel lainnya. Hal ini disebabkan oleh tidak adanya penambahan tepung sagu pada perlakuan 403, formula 403 menggunakan tepung terigu $100 \%$ dan bahan lainnya sama dengan formula lainnya, sementara pada sampel 485, 378, 268, dan 396 tekstur yang dihasilkan kenyal, karena semakin banyak tepung sagu yang ditambahkan pada bolu maka semakin kenyal tekstur yang dihasilkan.

\section{KESIMPULAN DAN SARAN KESIMPULAN}

Adanya pengaruh subtitusi tepung terigu dengan tepung sagu terhadap tingkat kesukaan bolu kemojo yang dinilai dari hasil uji organoleptik yang menggunakan 4 indikator. Tingkat kesukaan rasa, aroma, warna dan tekstur. Formula yang paling disukai adalah formula 378 dengan subtitusi 50\% tepung terigu dengan $50 \%$ tepung sagu.

\section{SARAN}

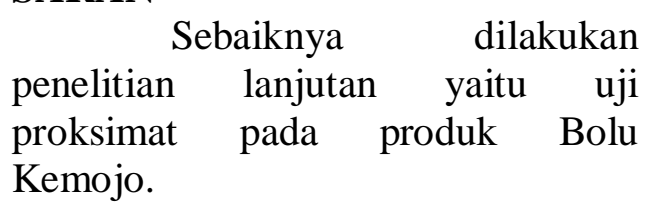

\section{DAFTAR PUSTAKA}

Achmad, F.B., P.A. Williams, J.L. Doublier, S. Durand, and A. Buleon. 1999. Physicochemical Characterization of Sago Starch. Carbohydrate Polymers. 38: 361-370.

[DKBM] Daftar Komposisi Bahan Makanan. 2009. Tabel Komposisi Pangan Indonesia.Jakarta: PT Elex Media Komputindo.

Hengky, N., 2003, Sagu Untuk Ketahanan Pangan, Pusat Penelitian dan Pengembangan Perkebunan, Manado

Jumantara, Bayu Agus. (2011). Modifikasi Selulosa Ampas Sagu dengan Polimerisasi Pencangkokan dan Penautan Silangan. Departemen Kimia Fakultas Matematika Dan Ilmu Pengetahuan Alam Institut Pertanian Bogor. 
Kementerian pertanian, 2016.

Statistik perkebunan Indonesia 2015-2017. DirektoratJenderal Perkebunan. Jakarta.

Murtiningsih dan Suyanti. 2011. Membuat Tepung Umbi dan Variasi Olahannya. Agro Media Pustaka. Jakarta.

Sangadji, I. 2009. Mengoptimalkan Pemanfaatan Ampas Sagu Sebagai Pakan Ruminansia Melalui Biofermentasi dengan jamur Tiram (Pleurotus ostreatus) dan Amoniasi. Disertasi. Sekolah Pascasarjana Institut Pertanian Bogor. Bogor.

Tribunnews.com, 2018.

http://pekanbaru.tribunnews.co m/2015/11/02/bolu-kemojooleh-oleh-khas-pekanbaru. Diakses Tanggal 12 Maret 2018 